Journal of Educational

Technology \& Online Learning

Volume 4 | Issue $4 \mid 2021$

http://dergipark.org.tr/jetol

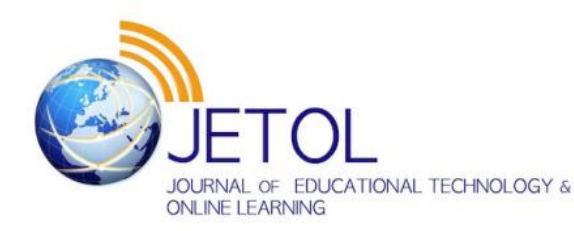

\title{
The effect of the training program of digital game design and escape rooms on science and art center teachers' technology acceptance, digital game development self-efficacy and use of digital games*
}

\author{
Sibel YOLERI ${ }^{\text {a* }}$ (D), Gizem UYUMAZ b ${ }^{\text {D }}$ \\ a İzmir Democracy University, Turkey \\ ${ }^{\mathrm{b}}$ Giresun University, Turkey
}

Suggested citation: Yoleri, S., \& Uyumaz, G. (2021). The effect of the training program of digital game design and escape rooms on science and art center teachers' technology acceptance, digital game development self-efficacy and use of digital games. Journal of Educational Technology \& Online Learning, 4(4), 793-804.

\begin{tabular}{l} 
Article Info \\
\hline Keywords: \\
Gifted students \\
Teachers \\
Digital game \\
Game design \\
Escape room
\end{tabular}

Research Article

\begin{abstract}
In this research, it is aimed to evaluate the effectiveness of digital game design and escape room training given to teachers working with gifted students in Science and Art Centers within the scope of 4005 Science and Society Innovative Education Practices Program supported by The Scientific and Technological Research Council of Turkey (TÜBİTAK) on their technology acceptance, use of digital games, and digital game development selfefficacy. In this context, a single group pre-test post-test model was used in the study carried out with the experimental design. The sample group was determined according to criterion sampling, one of the purposeful sampling techniques. 30 teachers working in different disciplines in six Science and Art Centers in İzmir were included in the study. Within the scope of the research, six-day trainings were given to the teachers by eight field experts. As data collection tools, "knowledge and awareness test on the use of technology in education and digital games", "technology acceptance scale for teachers", "digital educational game development self-efficacy scale" and "the scale of benefiting from digital games in education" were used. Whether there is a significant difference between the mean scores was tested with the dependent samples t test when the normality assumption was met, and with the Wilcoxon signed ranks test when it was not. As a result of the analysis, it was determined that there was a significant difference between the use of digital games, technology acceptance, digital game development self-efficacy and achievement test scores, and these differences were in favor of the post-tests. In addition, according to the scores obtained from the scales, it was determined that there was no significant difference in terms of the gender of the teachers and the education was effective for both genders.
\end{abstract}

\section{Introduction}

The acceleration of globalization and the advancements of information and communication technologies have increased the importance of information, access to information, production based on information and using information in business processes (Erten, 2019). The number of institutions doing business based on information and the number of employees with 21 st century skills who do business based on information have increased significantly in recent years. According to the World Economic Forum's Future of Jobs Report, fifty percent of all workers will need to acquire new skills by 2025 . Among these skills creativity

\footnotetext{
* Corresponding author. İzmir Democracy University, Turkey.

e-mail address: sibel.yoleri@idu.edu.tr

This study was partly presented as a proceeding at the 1st International Conference on Educational Technology and Online Learning Conference held between 22-24 September 2021.
} 
and innovation, critical thinking and problem solving, communication, collaboration, information management, effective use of technology, career and life skills, and cultural awareness stand out in most of the studies (Beers, 2006).

There are studies showing that educational digital games can be used effectively in the development of 21 st century skills. Digital games offer the opportunity to learn by doing, by appealing to more than one sense (Dönmez Usta \& Turan Güntepe, 2019). In this way, digital games may contain features that support 21st century skills such as complex problem solving, critical thinking, analytical thinking, etc. (Bayirtepe \& Tüzün, 2007). Some of the reasons for using digital games in the classroom can be counted as attracting attention, maintaining motivation and interest, having rich visual content, shortening learning time, and supporting meaningful learning (Çakir, 2013; Doğusoy \& İnal, 2006). Digital game-based learning can benefit educators thanks to its features such as the longer attention span of learners in these environments, the fact that these environments support lifelong learning, and the opportunity to easily teach any subject to individuals of all ages. (Prensky, 2001 a, 2001b). In this regard, both educational institutions and teachers should equip and develop themselves to better meet the needs of the new generation (Çankaya \& Karamete, 2008). Figure 2 shows the number of articles about digital game-based learning in web of science database by year.

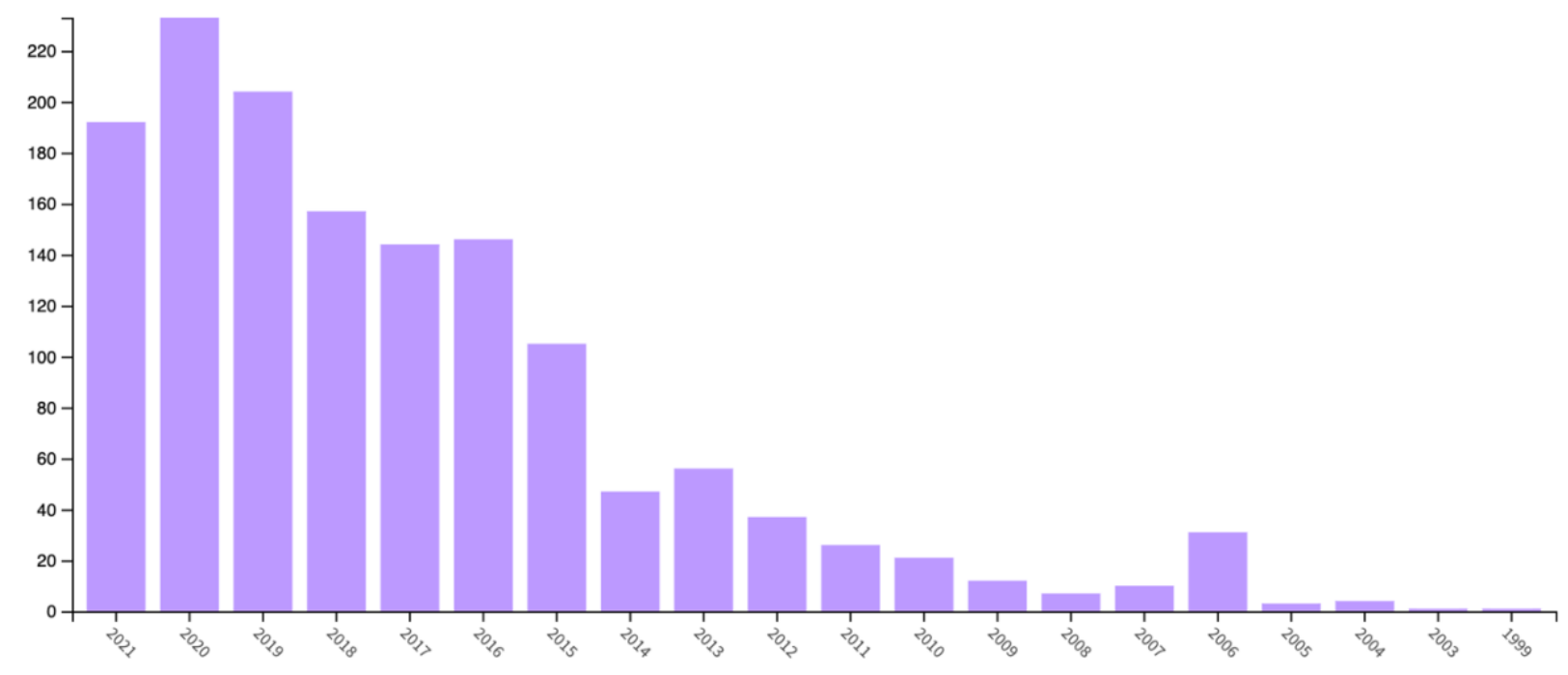

Figure 1. Number of articles about digital game-based learning in web of science database by year (Search Date: October 1, 2021)

As can be seen in Figure 1, digital game-based learning is an issue that attracts the attention of researchers in the literature, and it can be said that the number of studies on this subject has increased even more after 2015. It can be predicted that the interest in this field will increase gradually, as game technology develops and game development becomes easier than in the past.

In recent years, escape rooms have emerged and started to be used for educational purposes. Escape rooms are team-based action games with tasks similar to those in digital games but played in real environments. Players need to figure out how to accomplish a task to gain something, usually escape a room in a limited amount of time. In order to do this, players have to discover clues, solve puzzles. Gamemaster is the director of the game, who designs the environment by arranging things, putting clues in hidden places, giving puzzles, etc., defines the rules of the game and briefs players about the game and tasks to be accomplished. Gamemaster can ask players to watch a video or read a story about the game. Game starts and players work together as teams by looking everywhere to find clues aggressively to be able to escape the room first. The 
task can be quite complex that requires solving several clues, and puzzles which solving one clue or puzzle may lead to discover another clues and puzzles to be solved. Escape rooms require collaboration, problem solving, critical thinking, creative thinking, attention to details just like digital games (Jambhekar et al., 2020; Nicholson, 2015). Mayer and Toates (2016) stated that escape rooms take on the challenge and social participation of video games and expand this experience to make the real world part of the game. So, it can be said that escape rooms and digital games are similar in a way. On the other hand, applications of escape rooms in education are increasing, but many are not rigorously documented (Moura \& Santos, 2019). Figure 2 shows the number of articles about escape rooms in web of science database by year.

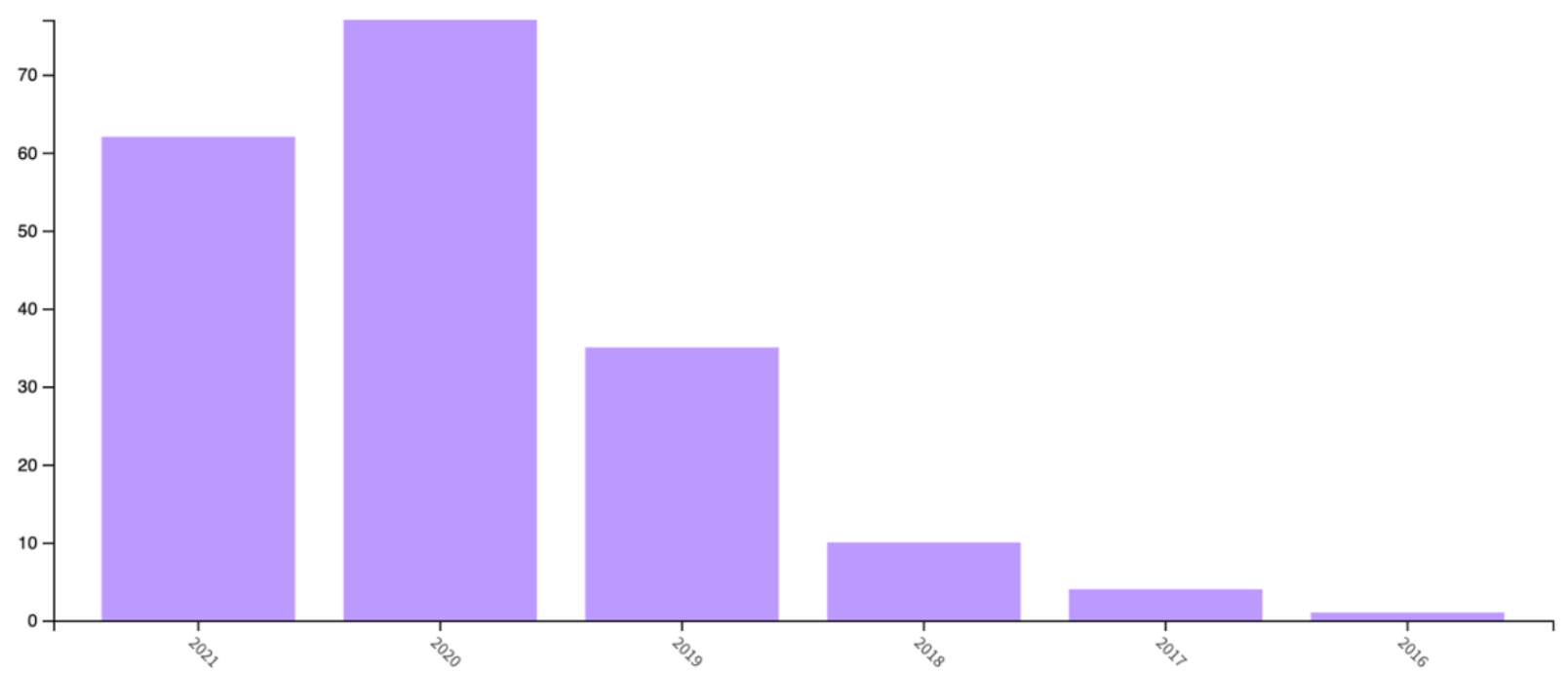

Figure 2. Number of articles about escape rooms in web of science database by year (Search Date:

October 1, 2021)

As can be seen in Figure 2, the topic of the escape rooms has attracted the attention of researchers especially in recent years (Borrego et al., 2017; Fuentes-Cabrera et al., 2020; Nicholson, 2015; Miller, 2015). In this context, the subject needs to be researched with different dimensions and new studies should be carried out. Moreover, it can be said that it will be beneficial for teachers to be trained in the development of digital games and Escape Rooms to design and develop useful digital content and activities for students. In this study, a training program was planned and implemented to improve teachers' awareness and skills on this subject. In this research, it is aimed to evaluate the effectiveness of digital game design and escape room training given to teachers working with gifted students in Science and Art Centers within the scope of 4005 Science and Society Innovative Education Practices Program supported by The Scientific and Technological Research Council of Turkey (TÜBİTAK) on their technology acceptance, use of digital games, and digital game development self-efficacy.

\section{Methodology}

\subsection{Research Model/Design}

The quantitative research method was employed in the study. A single group pre-test and post-test quasiexperimental design that the researcher collects data before and after the experimental intervention (Fraenkel, Wallen, \& Hyun, 2012) was used. This model helps to assess the significance of the difference between the pre-test and the post-test (Cresswell, 2016). 


\subsection{Data Collecting Tools}

In this study, the Use of Technology and Digital Games in Education Achievement Test, which was developed by the researchers and used for assessing questions containing the theoretical topics covered were prepared. A total of 20 multiple-choice questions consisted of the item pool of the study. The questions in the pool and the table of specifications were examined regarding content validity from the perspectives of assessment and evaluation and field education by 3 experts per field. The questions were revised according to the feedback given by the experts.

Digital Educational Game Development Self-Efficacy Scale: The scale was developed by Kelleci and Kulaksiz (2020). Consisting of 21 items, the scale has a two-factor structure defined as "Education" and "Game Development". The Cronbach Alpha reliability coefficient of all items was found to be 0.972 , while this value was calculated as 0.836 for the first sub-dimension and 0.973 for the second sub-dimension.

Technology Acceptance Scale for Teachers: This is a measurement tool adapted to determine teachers' approaches to gamification and developed to better understand teachers' use and acceptance of technology. The scale was adapted to Turkish culture by Ursavaş, Şahin and Mcilroy (2014). Validity and reliability analyze were carried out within the scope of the adaptation of the scale to Turkish culture, and a total of 37 items were gathered under 11 factors (perceived usefulness, perceived ease of use, attitude towards use, subjective norm, self-efficacy, facilitating situations, technological complexity, anxiety, perceived fun, relevance, and behavioral intention). In the analyzes conducted for the adaptation of the scale, it was stated that the lowest value of the Cronbach Alpha coefficient was 0.798 for the self-efficacy factor and the highest one was 0.909 for the perceived fun factor.

Utilizing Digital Games Attitude Scale: This scale was developed by Gormez (2020) in order to determine teachers' attitudes towards using digital games. Consisting of 17 items, the scale has a 4-factor structure. These factors are attitudes about using digital games in the lesson, attitudes towards the negative aspects of digital games, attitudes towards the positive aspects of digital games and the effects of digital games on learning in the classroom and students. In the analyzes performed to develop the scale, the Cronbach Alpha reliability coefficient was calculated as 0.916 for all items, 0.903 for the first sub-dimension, 0.855 for the second sub-dimension, 0.755 for the third sub-dimension, and 0.838 for the fourth sub-dimension.

\subsection{Study Group}

Having been conducted in order to improve the knowledge and skills of Science and Art Center teachers with innovative educational practices for gifted individuals, this study has determined 30 teachers working in science and art high schools located in Izmir province as the target audience. With the criterion sampling, which is one of the purposeful sampling methods, the participants were determined from among the teachers working in the science and art centers in İzmir (Ylldırım \& Şimşek, 2011). An online form has been sent to Science and Art Centers for the identification of participants. The selection of the participants was made based on the information that the participants filled out in the forms. Utmost attention was paid to the fact that teachers from each science and art center took part in the study, and participants were accepted from six science and art centers located in Izmir province. Although 30 teachers participated in the project, they were not included in the study due to the problems experienced with the forms of a teacher and the evaluation was conducted with 29 teachers. The study group of the research consists of 29 Science and Arts Centers teachers, $18(62.1 \%)$ of whom were female and the remaining $11(37.9 \%)$ were male.

\subsection{Data Analysis}

Within the scope of the study, firstly missing values and outliers were examined. The outliers were analyzed by converting item scores on the scale to standard z scores (Tabachnick \& Fidel, 2001). There are no individuals whose standard scores were outside the $\pm 4 \mathrm{z}$ range (Mertler \& Vannata, 2005) and no missing values in the data set. Statistical significance was set at $\mathrm{p}<0.05$. SPSS (version 26.0) and TAP: Test Analysis Program (version 19.1.4) package programs were used in the analysis. 
The normality of the test score distributions of both pre and post tests were investigated. Corresponding results are represented in Table 1.

Table 1.

Tests of Normality

\begin{tabular}{lcccccc}
\hline & \multicolumn{3}{c}{ Shapiro-Wilk } & & \\
\cline { 2 - 4 } Score & Statistic & df & Sig. & & Skewness & Kurtosis \\
\hline Utilising Pre-test &, 980 & 29 &, 837 & $-0,115$ & $-0,647$ \\
Utilising Post-test &, 982 & 29 &, 890 & $-0,261$ & $-0,003$ \\
Self-efficacy Pre-test &, 936 & 29 & $\mathbf{, 0 8 0}$ & 0,957 & $\mathbf{1 , 4 6 4}$ \\
Self-efficacy Post-test &, 947 & 29 &, 151 & $-0,109$ & $-0,827$ \\
Acceptance Pre-test &, 966 & 29 &, 465 & 0,037 & $-0,734$ \\
Acceptance Post-test &, 965 & 29 &, 425 & 0,039 & $-0,714$ \\
Achievement Pre-test &, 903 & 29 & $\mathbf{, 0 1 1}$ & $-0,548$ & $-0,343$ \\
Achievement Post-test &, 921 & 29 & $\mathbf{, 0 3 3}$ & $-0,361$ & 0,200 \\
\hline
\end{tabular}

When Table 1 is examined, it can be observed that Utilising pre-test and post-test grades and Acceptance pre-test grades were normally distributed. Therefore, parametric techniques (paired samples t test) were employed when these results were being analyzed. For other grades that are present in the Table 1, nonparametric techniques (the Wilcoxon signed-ranks test) were used.

The normality of the test score distributions in female and male groups of both pre and post tests were investigated. Corresponding results are represented in Table 2.

Table 2.

Tests of Normality

\begin{tabular}{|c|c|c|c|c|c|c|}
\hline & & & -Wi & & & \\
\hline & Gender & Statistic & df & Sig. & Skewness & Kurtosis \\
\hline Utilising Pre-test & Female & ,957 & 18 &, 545 & $-0,602$ & $-0,217$ \\
\hline & Male & ,934 & 11 & ,454 & 0,623 & $-0,347$ \\
\hline Utilising Post-test & Female & ,930 & 18 & , 191 & $-0,667$ & 0,382 \\
\hline & Male & ,939 & 11 & ,504 & 0,734 & 0,059 \\
\hline Self-efficacy Pre-test & Female & ,904 & 18 & 069 & 0,990 & 0,482 \\
\hline & Male & ,944 & 11 & ,568 & 0,147 & $-1,325$ \\
\hline Self-efficacy Post-test & Female & ,955 & 18 & ,502 & 0,057 & $-0,953$ \\
\hline & Male & ,937 & 11 & ,488 & $-0,410$ & 0,107 \\
\hline Acceptance Pre-test & Female & 960 & 18 & 608 & 0,135 & $-0,782$ \\
\hline & Male & ,984 & 11 & ,983 & $-0,009$ & $-0,299$ \\
\hline Acceptance Post-test & Female & ,954 & 18 & ,494 & 0,273 & $-0,669$ \\
\hline & Male & ,919 & 11 & ,307 & 0,129 & $-1,609$ \\
\hline Achievement Pre-test & Female & ,942 & 18 & 319 & $-0,300$ & $-0,270$ \\
\hline & Male & ,813 & 11 &, 014 & $-0,969$ & $-0,065$ \\
\hline Achievement Post-test & Female & ,941 & 18 & 299 & $-0,322$ & $-0,013$ \\
\hline & Male &, 864 & 11 & ,066 & 0,457 & $-1,466$ \\
\hline
\end{tabular}

When Table 2 is examined, it can be observed that Self-efficacy pre-test, Acceptance post-test and Achievement pre-test and post-test male grades were not normally distributed. For these grades, nonparametric techniques (Mann Whitney $U$ test) were used. For other grades that are present in the Table 2, parametric techniques (the independent samples t-test) were used. 


\subsection{Validity and Reliability}

The reliability proofs were obtained with Cronbach's alpha for scales and KR-20 (Kuder-Richardson Formula 20, which is a special case of coefficient alpha) coefficient for achievement test.

Cronbach's alpha internal consistency coefficients calculated to determine the reliability of data collected are presented in Table 3.

Table 3.

Reliability Coefficients

\begin{tabular}{lllllll}
\hline & $\begin{array}{l}\text { Acceptance } \\
\text { Pre-test }\end{array}$ & $\begin{array}{l}\text { Acceptance } \\
\text { Post-test }\end{array}$ & $\begin{array}{l}\text { Utilising } \\
\text { Pre-test }\end{array}$ & $\begin{array}{l}\text { Utilising } \\
\text { Post-test }\end{array}$ & $\begin{array}{l}\text { Self-efficacy } \\
\text { Pre-test }\end{array}$ & $\begin{array}{l}\text { Self-efficacy } \\
\text { Post-test }\end{array}$ \\
\hline Cronbach's alpha & 0,911 & 0,889 & 0,896 & 0,869 & 0,972 & 0,975 \\
\hline Number of Item & 38 & 38 & 17 & 17 & 21 & 21 \\
\hline
\end{tabular}

When Table 3 is analyzed, it is concluded that the Cronbach's alpha internal consistency coefficients for all scores have high reliability levels (Özdamar, 2004).

Item difficulty index (between zero and one) and item discrimination index (vary from -1.00 to 1.00) are calculated in item analyses of a test. After analyzing the gathered data, the final questionnaire included 11 questions that have the best distinctiveness and have mid-level difficulty while considering the distribution of the questions with respect to the gains. Items whose difficulty levels were lower than 0.30 or higher than 0.70 were removed because they were too difficult or too easy items. Items whose discrimination levels were lower than 0.30 were removed because they were not distinctive.

The final item and test analysis results are presented in Table 3.

\section{Table 4.}

Item and Test Analysis

\begin{tabular}{lcccl}
\hline Item & Item Diff. & Item Disc. & Point Biserial & \\
\hline 1 & 0,50 & 0,69 & 0,59 & \\
2 & 0,76 & 0,46 & 0,49 & \\
3 & 0,60 & 0,73 & 0,66 & \\
4 & 0,53 & 0,42 & 0,44 & Mean Item Difficulty=0,531 \\
5 & 0,31 & 0,37 & 0,49 & Mean Discrimination Index $=0,526$ \\
6 & 0,31 & 0,51 & 0,53 & Mean Point Biserial=0,510 \\
7 & 0,53 & 0,76 & 0,58 & \\
8 & 0,66 & 0,35 & 0,37 & KR-20=0,717 \\
9 & 0,60 & 0,44 & 0,46 & Split-Half Reliability (with Spearman-Brown) $=0,757$ \\
10 & 0,47 & 0,53 & 0,54 & \\
11 & 0,57 & 0,54 & 0,45 & \\
\hline
\end{tabular}

When Table 4 is examined, it can be observed that the minimum item difficulty is 0,310 , maximum item difficulty is 0,759 . Item difficulty $<0.30=$ difficult; $0.30-0.70=$ moderate; $>0.70=$ easy (Reynolds, Livingstone \& Willson, 2009). The minimum discrimination index is 0,350 , maximum discrimination index is 0,758 . Item discrimination $<0.20$ should be discarded, 0.20-0.29 should be fixed and improved, 0.300.39 pretty good, 0.40 and above very good (Atılgan, Kan ve Aydın, 2017). The minimum point biserial is 0,374 , maximum point biserial is 0,656 . The KR-20 reliability coefficient was found to be 0.717 . The test is considered reliable if it has the reliability index of at least 0.70 (Schober, Boer \& Schwarte, 2018).

Wilcoxon Signed Ranks results are presented in Table 5. 
Table 5.

Difference between pre-test scores and post-test scores of the participants-1

\begin{tabular}{|c|c|c|c|c|c|c|}
\hline & & $\mathrm{N}$ & Mean Rank & Sum of Ranks & $\mathrm{Z}$ & Sig. \\
\hline Self-efficacy Post-test - Self- & Negative Ranks & $2^{\mathrm{a}}$ & 1,50 & 3,00 & $-4,556^{b}$ & ,000 \\
\hline \multirow{3}{*}{ efficacyPre-test } & Positive Ranks & $26^{\mathrm{b}}$ & 15,50 & 403,00 & & \\
\hline & Ties & $1^{\mathrm{c}}$ & & & & \\
\hline & Total & 29 & & & & \\
\hline Achievement Post-test - & Negative Ranks & $1^{\mathrm{d}}$ & 15,50 & 15,50 & $-4,379^{b}$ & ,000 \\
\hline \multirow[t]{3}{*}{ AchievementPre-test } & Positive Ranks & $28^{\mathrm{e}}$ & 14,98 & 419,50 & & \\
\hline & Ties & $0^{f}$ & & & & \\
\hline & Total & 29 & & & & \\
\hline
\end{tabular}

a. $\&$ d. : post < pre, b. \& e. : post > pre, c. \& f. : post $=$ pre

When Table 5 was examined, it was observed that the difference between pre-test and post-test for both Self-efficacy $(Z=4,556, p=0,000)$ and Achievement $(Z=4,379, p=0,000)$ was indeed statistically significant. This difference is in favour of positive ranks, which means on both scores, teachers' post-test scores were higher than their pre-test scores. Given "Digital Game Design and Escape Rooms Training Program" increased the relevant scores of the participants.

The paired samples $t$ test results are presented in Table 6 .

Table 6.

Difference between pre-test scores and post-test scores of the participants-2

\begin{tabular}{lcccccc}
\hline & Mean & N & Std. Deviation & t & df & Sig. (2-tailed) \\
\hline Utilising Pre-test & 64,6207 & 29 & 8,39393 & $-4,158$ & 28 &, 000 \\
Utilising Post-test & 69,5517 & 29 & 7,65127 & & & \\
Acceptance Pre-test & 138,2414 & 29 & 16,86004 & $-2,196$ & 28 &, 037 \\
Acceptance Post-test & 143,5172 & 29 & 14,66195 & & & \\
\hline
\end{tabular}

When Table 6 was examined, it was observed that the difference between pre-test and post-test for both Utilising $\left(\mathrm{t}_{(28)}=4,158, \mathrm{p}=0,000\right)$ and Acceptance $\left(\mathrm{t}_{(28)}=2,196, \mathrm{p}=0,037\right)$ was indeed statistically significant. On both scores, teachers' post-test scores were higher than their pre-test scores. Given "Digital Game Design and Escape Rooms Training Program" increased the relevant scores of the participants.

The results of the independent samples t-test is presented in Table 7 and the results of Mann Whitney U test were presented in Table 8.

Table 7.

The significance of the difference between gender-1

\begin{tabular}{llllcccc}
\hline & Gender & $\mathrm{N}$ & Mean & Std. Deviation & $\mathrm{t}$ & $\mathrm{df}$ & Sig. (2-tailed) \\
\hline Utilising Pre-test & Female & 18 & 65,1667 & 8,27647 &, 433 & 20,044 &, 669 \\
& Male & 11 & 63,7273 & 8,91169 & & & \\
Utilising Post-test & Female & 18 & 69,8889 & 8,16657 &, 299 & 27 &, 768 \\
& Male & 11 & 69,0000 & 7,07107 & & & \\
Self-efficacy Post-test & Female & 18 & 82,8889 & 13,19933 &,- 595 & 27 &, 557 \\
& Male & 11 & 85,8182 & 12,25413 & & & \\
Acceptance Pre-test & Female & 18 & 136,7222 & 17,90434 &,- 614 & 27 &, 545 \\
\hline
\end{tabular}




\section{Male}

11

140,7273

15,49252

Table 8.

The significance of the difference between gender-2

\begin{tabular}{lllcccc}
\hline & Gender & N & Mean Rank & Sum of Ranks & U & Sig. (2-tailed) \\
\hline Self-efficacy Pre-test & Female & 18 & 13,75 & 247,50 & 76,500 &, 311 \\
& Male & 11 & 17,05 & 187,50 & & \\
Acceptance Post-test & Female & 18 & 13,53 & 243,50 & 72,500 &, 233 \\
& Male & 11 & 17,41 & 191,50 & & \multirow{2}{*}{096} \\
Achievement Pre-test & Female & 18 & 13,00 & 234,00 & 63,000 & \\
& Male & 11 & 18,27 & 201,00 & & \multirow{2}{*}{358} \\
Achievement Post- & Female & 18 & 13,89 & 250,00 & 79,000 & \\
test & Male & 11 & 16,82 & 185,00 & & \\
\hline
\end{tabular}

When Table 7 and Table 8 were examined, it can be seen that the difference between gender was not statistically significant $(\mathrm{p}>0.05)$ for all scale scores. This result indicates that the score levels in both groups were similar.

\section{Findings and Discussions}

This study aims to evaluate the effectiveness of digital game design and escape rooms training provided by a TUBITAK project supported by 4005 Science and Society Innovative Educational Applications to teachers working with special talented students in Science and Art Centers on their technology acceptance, use of digital games, and digital game development. The primary aims of the project were to inform Science and Art Center teachers about new approaches and to increase the variety of teaching approaches and methods they will use in their lessons. Education is an important factor in the development of societies. Educated individuals, who are the most valuable resources of their societies, need to have certain qualifications in order to realize this harmony (AACU, 2007; National Association of Colleges and Employers, 2019). According to the report "The Future of Professions" of the World Economic Forum, fifty percent of all employees will need to acquire new skills by 2025 as technological adaptations increase. Among these skills, "Analytical thinking and innovation", "active learning and learning strategies", "complex problem solving", "critical thinking and analysis", "creativity, originality and initiative", "technology use", "technological design and programming" come to the fore. Teachers are the people who will set an example for the student in every sense and will provide them with the education according to the norms of 21st century. For this reason, the development of teachers' skills is a situation that should be given great importance. In a study conducted with pre-service teachers, these teachers mentioned that among the things to be done to acquire 21 st century skills, they need studies mostly under "information, media and technology skills" and then "21st century support systems", "life and career skills", "learning and renewal skills" and "basic topics and themes" respectively (Erten, 2019; Ndibalema, 2020).

According to the results obtained from the research, it is seen that the digital game development selfefficacy and success of science and art center teachers increased after digital game design and escape rooms training. In their study, Martins and Oliveira (2018) revealed that teachers' digital educational game development competencies were low. In the same study, it was emphasized that teachers with high digital 
game development skills also increase the motivation and learning levels of their students. In the studies, it has been determined that teachers faced various problems in accepting technology and integrating it into their lessons, and they needed support, and if they receive training, they could develop positive perceptions in this regard (Robin, 2008).

Another result of the study is that after digital game design and escape rooms training, science and art center teachers' levels of using digital games and accepting technology have increased. Many teachers consider digital games only as motivational tools and cannot adequately use their educational benefits (Gaudelli, \& Taylor, 2011; Schrader, Zheng, \& Young, 2006). Whereas digital games allow students to learn by doing and help them develop transferable knowledge and skills by allowing them to apply newly learned skills in various situations (An \& Bonk, 2009; Shaffer, Squire, Halverson, \& Gee, 2005; Kaldırım, \& Tavşanlı, 2021). According to several research results, the integration and use of digital educational games in the school environment could effectively contribute to the reformation of the educational system (Deng et al., 2020; Hawlitschek, \& Joeckel, 2017). In their study, Takeuchi and Vaala (2014) reported that more than half of the teachers use digital games to motivate and reward students. The results of the studies conducted by Sardone and Devlin-Scherer (2010) and Kennedy-Clark, Galstaun and Anderson (2011) showed that the education given to pre-service teachers about digital games contributed to their developing positive attitudes about using them.

The pre-test and post-test scores of the training given within the scope of the study were not differentiated according to gender. In other words, the training provided did not make a difference in terms of gender. This result shows that there are no examples or applications specific to only one group in the trainings conducted and that they are suitable for teachers of both genders. In their study, Kozikoglu and Altunova (2018) found that the pre-service teachers' perceptions of 21 st century skills such as information and media technology or learning and innovation were at a high level and there was no significant difference according to gender. Ayra and Köserlioğlu (2016) did not find a significant difference in the teaching self-efficacy beliefs between male and female teachers.

\section{Conclusion and Suggestions}

As a result of the study, it has been revealed that ensuring the sustainability of learning is only possible through the possession of various technological skills, and it is necessary to develop these knowledge and skills on a constant basis. In order to develop the skills that individuals should have and need, training and education programs should be supported and strengthened in this direction. Then, it should be ensured that the awareness of teachers and teacher candidates who will take part in this education and training should be increased and raised, and that they should be equipped and become competent with these skills first. With the dissemination and diversification of the trainings provided within the scope of the study, it will be possible for teachers to reach innovative methods and techniques in order to gain these skills. The teacher is an important factor in the learning and development of gifted students, and the increase of teachers' professional development will eventually increase student motivation and success. The project is primarily aimed at creating an impact on teachers, and this created effect shall have an impact on the success and motivation of students with special abilities.

Although the training provided within the scope of the study are effective, there are some limitations. Teachers working in Science and Art Centers throughout Turkey could not be included in the study due to the pandemic. In later project calls, this scope can be expanded and a new application can be made. The 
project topic and trainings have been planned by reviewing the current developments and needs, but in future studies, topics can be determined by analyzing the needs before planning the training.

Acknowledgements: The project team gratefully acknowledges the Scientific and Technological Research Council of Turkey (TUBITAK) for supporting the project (Project Number:121B271).

\section{References}

An, Y., \& Bonk, C. J. (2009). Designing digital game-based learning environments. TechTrends, 53(3), 4348.

Association of American Colleges and Universities (2007). College learning for the new global century: A report from the national leadership council for liberal education \& America's promise. https://eric.ed.gov/?id=ED495004

At1lgan, H., Kan, A., \& Aydın, B. (2017). Measurement and evaluation in education (10th Edition). An1 publishing.

Ayra, M., \& Kösterelioğlu, İ. (2016). Öğretmenlerin mesleki öz-yeterlik inançlarının çeşitli değişkenler açısından incelenmesi. Gümüşhane Üniversitesi Sosyal Bilimler Enstitüsü̈ Elektronik Dergisi, 7(17), 81-101.

Bayirtepe, E., \& Tüzün, H. (2007). Oyun-tabanlı öğrenme ortamlarının öğrencilerin bilgisayar dersindeki başarıları ve öz-yeterlik algıları üzerine etkileri. Hacettepe Üniversitesi Eğitim Fakültesi Dergisi, $33,41-54$.

Beers, S. Z. (2006). 21st century skills: Preparing students for their future. https://cosee.umaine.edu/files/coseeos/21st century skills.pdf

Borrego, C., Fernández, C., Blanes, I., \& Robles, S. (2017). Room escape at class: Escape games activities to facilitate the motivation and learning in computer science. JOTSE, 7, 162-171.

Cresswell, J.W. (2016). Araştırma deseni nitel, nicel ve karma yöntem yaklaşımları. (S. B. Demir, Trans.) Eğiten Kitap.

Çakir, H. (2013). Bilgisayar oyunlarına ilişkin ailelerin yaklaşımı ve öğrenci üzerindeki etkilerin belirlenmesi. Mersin Üniversitesi Eğitim Fakültesi Dergisi, 9(2), 138-150. https://doi.org/10.17860/efd.89744

Çankaya, S., \& Karamete, A. (2008). Eğitsel bilgisayar oyunlarının öğrencilerin matematik dersine ve eğitsel bilgisayar oyunlarına yönelik tutumlarına etkisi. Mersin Üniversitesi Eğitim Fakültesi Dergisi, 4(2), 115-127. https://doi.org/10.17860/efd.31845

Deng, L., Wu, S., Chen, Y., \& Peng, Z. (2020). Digital game-based learning in a Shanghai primary-school mathematics class: A case study. J. Comput. Assist. Learn, 36, 709-717.

Doğusoy, B., \& İnal, Y. (2006). Çok kullanıcılı bilgisayar oyunları ile öğrenme. VII. Ulusal Fen Bilimleri ve Matematik Eğitimi Kongresi.

Dönmez Usta, N., \& Turan Güntepe, E. (2019). Dijital oyun tasarlamanın öğrenmeye Etkisi. Bingöl Üniversitesi Sosyal Bilimler Enstitüsü Dergisi, 9(18), 1215-1234. https://doi.org/10.29029/busbed.562553

Erten, P. (2019). Preservice teachers' perceptions of 21 st century skills competence and their views on gaining these skills. Milli Eğitim, 49(227), 33-64. 
Fraenkel, J.R., Wallen, N.E., \& Hyun, H.H. (2012). How to design and evaluate research in education. McGraw-Hill.

Fuentes-Cabrera, A., Parra-González, M.E., López-Belmonte, J., \& Segura-Robles, A. (2020). Learning Mathematics with Emerging Methodologies-The Escape Room as a Case Study. Mathematics, 8, 1586.

Gaudelli, W., \& Taylor, A. (2011). Modding the global classroom? Serious video games and teacher reflection. Contemporary Issues in Technology and Teacher Education, 11(1), 70-91.

Hawlitschek, A., \& Joeckel, S. (2017). Increasing the effectiveness of digital educational games: the effects of a learning instruction on students' learning, motivation and cognitive load. Comput. Educ. 72, 7986.

Jambhekar, K., Pahls, R. P., \& Deloney, L. A. (2020). Benefits of an escape room as a novel educational activity for radiology residents. Academic Radiology, 27(2), 276-283. https://doi.org/10.1016/j.acra.2019.04.021

Kaldırım, A. \& Tavşanlı, Ö. F. (2021). A thematic review of using digital teaching technologies in Turkish language teaching. Journal of Educational Technology \& Online Learning, 4(2), 70-95.

Kennedy-Clark, S., Galstaun, V., \& Anderson, K. (2011). Using game based inquiry learning to meet the changing directions of science education. In Proceedings of ASCILITE - Australian Society for Computers in Learning in Tertiary Education Annual Conference 2011 (pp. 702-714). Australasian Society for Computers in Learning in Tertiary Education.

Kozikoğlu, İ, \& Altunova, N. (2018). Öğretmen adaylarının 21. yüzyıl becerilerine ilişkin öz-yeterlik algılarının yaşam boyu öğrenme eğilimlerini yordama gücü [The Predictive Power of Prospective Teachers' Self-efficacy Perceptions of 21st Century Skills for Their Lifelong Learning Tendencies]. Yükseköğretim ve Bilim Dergisi, 8(3), 522-531. Doi: 10.5961/jhes.2018.293.

Martins, A.R., \& Oliveira, L.R. (2018, June). Students as Creators of Educational Games-Learning to Use Simple Frameworks and Tools to Empower Students as Educational Game Designers. In EdMedia+ Innovate Learning (pp. 1210-1215). Association for the Advancement of Computing in Education (AACE).

Mayer, B., \& Toates, L. (2016). All about escape rooms. School Library Journal. https://www.slj.com/?detailStory=all-about-escape-rooms

Mertler, C.A., \& Vannatta, R.A. (2005). Multiple regression. Advanced and multivariate statistical methods, 3rd Edition, Pyrczak, Los Angeles.165-198.

Miller, S. (2015). The art of the escape room. Retrieved from https://www.newsweek.com/2015/05/01/artescape-room-323150.html

Moura, A., \& Santos, I. L. (2019). Escape room in education: Gamify learning to engage students and learn Maths and Languages. In B. D. Silva, J. A. Lencastre, M. Bento, \& A. J. Osório (Eds.), Experiences and Perceptions of Pedagogical Practices with Game-Based Learning \& Gamification (pp. 179194). Research Centre on Education (CIEd) Institute of Education, University of Minho.

Ndibalema, P. (2020). Unlocking the potential of ICT for Transformative Learning among youth: A path to 21 st century competencies. Journal of Educational Technology \& Online Learning, 3(3), 245271.

National Association of Colleges and Employers. (2019). Job outlook 2019. https://www.odu.edu/content/dam/odu/offices/cmc/docs/nace/2019-nace-job-outlook-survey.pdf

Nicholson, S. (2015). Peeking behind the locked door: A survey of escape room facilities. In White Paper (pp. 1-35). http://scottnicholson.com/pubs/erfacwhite.pdf 
Prensky, M. (2001a). Digital game-based learning. McGraw-Hill.

Prensky, M. (2001b). Digital natives, digital immigrants part 1. On the Horizon, 9(5), 1-6. https://doi.org/10.1108/10748120110424816

Reynolds, C.R., Livingstone, R.B., \& V. Willson, V. (2009). Measurement and assessment in education (2nd edition), Pearson Education.

Robin, B.R. (2008). Digital storytelling: a powerful technology tool for the 21st century classroom. Theory into Practice, 47, 220-228.

Sardone, N., \& Devlin-Scherer, R. (2010). Teacher candidate responses to digital games: 21st century skills development. Journal of Research on Technology in Education, 42(4), 409-425.

Schober, P., Boer, C., \& L. Schwarte, L. (2018). Correlation coefficients: Appropriate use and interpretation, Anesth Analg., 126(5), 1763-1768.

Schrader, P. G., Zheng, D., \& Young, M. (2006). Teachers' perceptions of video games: MMOGs and the future of preservice teacher education. Innovate, 2(3), 1-7.

Shaffer, D.W., Squire, K.R., Halverson, R., \& Gee, J.P. (2005). Video games and the future of learning. Phi Delta Kappan, 87(2), 104-111.

Tabachnick, B. G., \& Fidel, L.S. (2001). Using multivarite statistics. Allyn and Bacon.

Takeuchi, L M., \& Vaala, S. (2014). Level up learning: A national survey on teaching with digital games. http://www.joanganzcooneycenter.org/wpcontent/uploads/2014/10/jgcc_leveluplearning_final.pdf 